\title{
Processes controlling the geochemical composition of the South China Sea sediments during the last climatic cycle
}

Youbin Sun ${ }^{1, *}$, Feng Wu ${ }^{1}$, Steven C. Clemens ${ }^{2}$, Delia W. Oppo ${ }^{3}$

${ }^{1}$ State Key Laboratory of Loess and Quaternary Geology, Institute of Earth Environment, Chinese Academy of Sciences, Xi'an 710075, China

2 Department of Geology, Brown University, Providence, RI 02912-1846, USA

${ }^{3}$ Department of Geology and Geophysics, Woods Hole Oceanographic Institution, Woods Hole, MA 02543, USA.

* Corresponding to Youbin Sun ( $\underline{\text { sunyb@ieecas.cn }})$

\begin{abstract}
Sediments of the upper 28.2 meters of Ocean Drilling Program (ODP) Site 1145 from the northern South China Sea (SCS) were analyzed for their geochemical composition. Most of the major and trace elements exhibit significant fluctuations at glacial-interglacial scales, implying a close relation with regional and global climate change. Al-normalized elemental ratios can be subdivided into three principal components (PC). PC1 (e.g., $\mathrm{Ca} / \mathrm{Al}, \mathrm{Ba} / \mathrm{Al}, \mathrm{Sr} / \mathrm{Al}$ ) displays significant glacial-interglacial variation and is related to paleoproductivity in the northern SCS. PC2 (e.g., K/Al, Mg/Al, Rb/Al) is associated with the degree of chemical weathering in the source regions and shows little glacial-interglacial variation. PC3 (e.g., $\mathrm{Ti} / \mathrm{Al}, \mathrm{Zr} / \mathrm{Al}$ ) reflects the relative contribution of coarse- and fine-grained materials in the terrigenous components of the SCS sediments, likely associated with changes in sea level and monsoon-induced fluvial input. Spectral analyses indicate that paleoproductivity (i.e., $\mathrm{Ba} / \mathrm{Al}$ ) in the South China Sea lags Hulu/Sanbao speleothem $\delta^{18} \mathrm{O}$ record (a indicator of annual average meteoric precipitation) by $102^{\circ}$ and Indian summer monsoon (multi-proxy stack) by $23^{\circ}$ at the precession band, indicating a close relationship with the Indian summer monsoon. However, the chemical weathering degree in the source area (PC2) is not sensitive to monsoon-related changes at the precession band during the last climatic cycle.
\end{abstract}


Key words: South China Sea; major and trace elements; elemental ratios; East Asian monsoon

\section{Introduction}

The South China Sea (SCS), with a total area of $3.5 \times 10^{6} \mathrm{~km}^{2}$, is a semi-enclosed marginal sea connected to the East China Sea through the Taiwan Strait, to the Pacific Ocean through the Bashi Strait, and to the Sulu Sea through the Mindoro and Balalao straits (Fig.1) (Wang et al., 1995). At present, the summer season is characterized by relatively weak ( $\sim 3 \mathrm{~m}$ $\left.\mathrm{s}^{-1}\right)$ southwesterly wind (summer monsoon) and strong precipitation $\left(9 \mathrm{~mm} \mathrm{~d}^{-1}\right)$ over the SCS. Conversely, the sea surface circulation during the winter season is controlled by strong $(8 \mathrm{~m}$ $\mathrm{s}^{-1}$ ) northeasterly winds (winter monsoon) that results in a cooling of surface water (Wang and Wang, 1990) and reduced precipitation $\left(2 \mathrm{~mm} \mathrm{~d}^{-1}\right)$. Similarly on glacial-interglacial cycles, the East Asian monsoon (EAM) has a profound influence on the local climatic and oceanographic processes, leading to reversal of the circulations and strong differences in sea surface temperature (SST) and salinity (SSS) (e.g., Wang and Wang, 1990; Wang, 1999; Wang et al., 1999).

Information from marine-based monsoon proxies complements inferences of past monsoon variability from terrestrial proxies (e.g., An, 2000; Wang et al., 2008). For the SCS, these marine proxies include: (1) mineralogical and sedimentological indicators (e.g., lithogenic grain size, smectite/(illite+chlorite) ratio) that are used to address variation of the winter and summer monsoons at glacial-interglacial timescales (e.g., Wang et al., 1999; Boulay et al., 2005, 2007; Liu et al., 2003; Tamburini et al., 2003); (2) elemental ratios that are employed to reconstruct the history of chemical weathering as a function of summer monsoon precipitation (e.g., $\mathrm{K} / \mathrm{Si}$ ) and the monsoon-induced surface productivity (e.g., $\mathrm{Ba} / \mathrm{Al}$ ) (e.g., Wehausen and Brumsack, 2002; Wei G.J. et al., 2003, 2004); (3) stable isotopic data (e.g., planktonic $\delta^{13} \mathrm{C}$, the difference in the planktonic $\delta^{18} \mathrm{O}$ between the SCS and Sulu Sea) that are suggested to reflected the summer monsoon strength (Wang et al., 1999; Wei K.Y. et al., 2003); and (4) sea surface temperature (SST) estimated from planktonic foraminifer counts, the $\mathrm{U}_{\mathrm{k}}{ }^{37}$ biomarker and $\mathrm{Mg} / \mathrm{Ca}$ ratio of the planktonic foraminifer Globigerinoides 
ruber (e.g., Wang et al., 1999; Pelejero et al., 1999; Kienast et al., 2001; Chen et al., 2003; Oppo and Sun, 2005; Zhao et al., 2006).

These monsoon proxies can be divided into two groups: proxies related to the monsoon winds (direction, strength and persistence), and proxies associated with monsoon-induced precipitation (chemical weathering intensity, fluvial input) (Wang et al., 2005). The integrity of each monsoon proxy depends on the extent to which it responds to the monsoon-related forcing. Additional processes sometimes complicate the interpretation of the physical, chemical and biological proxies in terms of their response to monsoon variability. For example, differentiating the sea level response from monsoon-related variations is difficult for grain size and pollen records from northern SCS sediments (Sun et al., 2003; Boulay et al., 2007). Moreover, previous interpretations of geochemical indicators generated from the SCS sediments are controversial, e.g., reflecting the chemical weathering intensity in south China (Wei et al., 2004) vs. fluvial contribution (Wehausen and Brumsack, 2002), although both are related to the summer monsoon intensity.

Here we present high-resolution (500 1000 year) major and trace element records from Ocean Drilling Project (ODP) Site 1145 over the last $145 \mathrm{kyr}$ and investigate their implications for monsoon-related changes in the northern SCS. Principal component analysis of the elemental ratios (normalized by $\mathrm{Al}$ ) allows characterization of three independent dominant modes of variability, enabling a distinct interpretation of their connections to the EAM and sea level change. By comparing multiple proxies (i.e., geochemical indicators and benthic $\delta^{18} \mathrm{O}$ records) generated from the same core with the speleothem $\delta^{18} \mathrm{O}$ records and the Indian summer monsoon stack, we assess mechanisms controlling the elemental variations and their potential links to changes in the EAM and sea level.

\section{Materials and methods}

ODP Site $1145\left(19^{\circ} 35^{\prime} \mathrm{N}, 117^{\circ} 38^{\prime} \mathrm{E}\right.$, at $3175 \mathrm{~m}$ water depth) is situated near the northern continental margin of the South China Sea (Fig.1) (Shipboard Scientific Party, 2000). The South China Sea is of primary importance for understanding of the relationship between global (glacial-interglacial sea level variation) and local (monsoon) climate changes (Wang, 
1999; Wang et al., 1999; Oppo and Sun, 2005). Today, surface waters at this site are warmest $\left(\sim 29^{\circ} \mathrm{C}\right)$ and freshest $(<33.5 \mathrm{psu})$ from June through August mainly due to fluvial runoff from the Pearl River (Wang et al., 1999). Surface waters are coldest $\left(\leq 25^{\circ} \mathrm{C}\right)$ and saltiest $(\geq 34 \mathrm{psu})$ from December through March, when a maximum inflow of northern subtropical Pacific water occurs through the Bashi Strait (Levitus and Boyer, 1994).

Geochemical analysis of this site has been carried out for the late Pliocene interval (Wehausen and Brumsack, 2002). Benthic oxygen isotope and $\mathrm{Mg} / \mathrm{Ca}$-based SST estimate have been generated from the upper portion of this core. Paleoclimatic implications of these data and the age model reconstruction have been detailed in Oppo and Sun (2005). In brief, the age model was generated on the basis of four radiocarbon dates in the younger portion of the record and correlation to the orbitally-tuned benthic $\delta^{18} \mathrm{O}$ stack (Martinson et al., 1987). In this study, a total of 276 samples were taken at 10-cm resolution from the upper 28.2 meters of ODP Site 1145 for geochemical analyses.

The samples were freeze-dried and then finely ground to 200 mesh size $(<74 \mu \mathrm{m})$ and homogenized in an agate mortar. Five grams of the powdered sample was compressed into a thin compact disc (approximate 3.2-cm in diameter). Concentrations of major (e.g., Si, Al, Ca, Fe) and trace elements (e.g. Zr, Rb, Sr, Ba) were analyzed using a Philips PW4400 X-Ray Fluorescence (XRF) spectrometer at the Institute of Earth Environment, Chinese Academy of Sciences. Calibration was done with sixteen Chinese national soil reference samples (from GSS-1 to GSS-16) and twelve sediment reference samples (from GSD-1 to GSD-12). Analytical precision, as verified by replicate analyses of GSS-8 and two core samples from the depth of 15.15 and $25.55 \mathrm{~m}$, was better than $1 \%$ for major elements and better than $5 \%$ for trace elements except for Co $(5.8 \%)$.

In the South China Sea, paleoclimatic and paleoceanographic records of monsoon variability are measured through indirect (proxy) indicators. These proxy indicators may be biotic, geochemical, isotopic, or physical in nature, but their variability is related, in part, to changes in the environment associated with the monsoon circulation (see a review by Wang et al., 2005). To extract the common variability of these proxy indicators, statistical methods (e.g., principal component analysis) are widely used (e.g., Clemens et al., 2003). Principal component analysis is a technique used to reduce multidimensional data sets using eigenvalue 
decomposition of a data covariance matrix or singular value decomposition of a data matrix (Jolliffe, 2002). The results are usually discussed in terms of component scores and loadings. In this study, the Al-normalized elemental ratios were input as variance and the principal component analysis was performed using the SPSS (Statistical Package for the Social Science, SPSS Inc.) software.

\section{Results}

\subsection{Major and minor elements}

Major and trace element results suggest that upper part of Site 1145 sediments is dominated by terrigenous materials (i.e., Si, Al, K, Mg, Ti, Zn, Rb, Zr, Ga, Nb) (Fig.2A) and biogenic components ( $\mathrm{CaO}$, and $\mathrm{Sr}$ ) (Fig.2B). In addition, $\mathrm{P}_{2} \mathrm{O}_{5}, \mathrm{Ba}, \mathrm{Zn}$ and $\mathrm{Co}$, related to oceanic productivity and organic matter burial (Wehausen and Brumsack, 2002; Wei et al., 2003), exhibit distinct variations at glacial-interglacial scales (Fig.2C). V, Y and Ni, possibly associated with organic matter burial (V) or iron sulfides (Ni) (Wehausen and Brumsack, 2002), display less variability at glacial-interglacial scales (Fig.2D). Compared to the geochemical results of the Pliocene interval of this site (Wehausen and Brumsack, 2002), average values of these elements are almost identical, except for $\mathrm{SiO}_{2}, \mathrm{CaO}$ and $\mathrm{Sr} . \mathrm{SiO}_{2}$ content is significantly higher in the upper section (60.56\%) compared to the lower portion (44.95\%), while average values of $\mathrm{CaO}(5.38 \%)$ and $\mathrm{Sr}(300 \mathrm{ppm})$ concentrations are slightly lower in the upper part relative to those in the Pliocene interval $(9.87 \%$ and $430 \mathrm{ppm}$ for $\mathrm{CaO}$ and Sr, respectively). These long-term trends are consistent with the shipboard data, implying an increased terrigenous input and/or dissolution of the carbonate shells related to changes in the sea level and the lysocline depth (Shipboard Scientific Party, 2000). The sedimentary records at ODP Sites 1145 contain similar relative contributions of each clay mineral and variations of major and trace elements through time compared to Site 1146 sediments (Shipboard Scientific Party, 2000; Liu et al., 2003; Wei et al., 2004; Boulay et al., 2005). This indicates that Site 1145 sediments have not been altered by early diagenesis and thus can be utilized for paleoenvironmental reconstruction of climatic-driven processes in northern SCS.

The elements of lithogenic origin exhibit different variation patterns and can be 
subdivided into two groups (Fig.2A). Group I contains $\mathrm{Al}_{2} \mathrm{O}_{3}, \mathrm{~K}_{2} \mathrm{O}, \mathrm{MgO}, \mathrm{Rb}, \mathrm{Cr}$ and $\mathrm{Ga}$, which are mainly found in clay minerals and enriched in the fine fraction (Wehausen and Brumsack, 2002; Zhang et al., 2002). Group II consists of $\mathrm{SiO}_{2}, \mathrm{TiO}_{2}, \mathrm{Zr}$ and $\mathrm{Nb}$, which are enriched in silt-sized minerals, e.g. quartz, titanite, zircon, rutile (Sirocko et al., 2000; Zhang et al., 2002). Although positive correlation (r>0.7) between $\mathrm{SiO}_{2}$ and other three elements $(\mathrm{Zr}$, $\mathrm{Ti}$ and $\mathrm{Nb}$ ) demonstrates that the $\mathrm{SiO}_{2}$ is mainly of lithogenic origin, biogenic opal may also have contributed to the $\mathrm{Si}$ accumulation since the upper part of Site 1145 is characterized by small amounts $(<10 \%)$ of biogenic silica, mainly in the form of radiolarians, diatoms, sponge spicules, and silicoflagellates (Shipboard Scientific Party, 2000). Temporal variations of the lithogenic elements of the two groups are almost identical during the last interglaciation but different since the beginning of the last glaciation. Concentrations of these elements display large-amplitude fluctuations during marine isotope stage (MIS) 5, with lower values during interstadials (MIS 5a, 5c and 5e) relative to stadials (MIS 5b and 5d). During the last glacial and Holocene, however, concentrations of elements in Group I are less variable and lower than values of the last interglacial interval. In contrast, concentrations of Group II elements exhibit distinct glacial-interglacial variations, with higher values during glacials (MIS 2, 4 and 6) and stadials (MIS 5b and 5d).

$\mathrm{CaO}$ and $\mathrm{Sr}$ show high variability at glacial-interglacial scales, inversely correlating with variations of the lithogenic elements in Group II (Fig.2B). High correlation ( $r>0.99)$ between $\mathrm{CaO}$ and $\mathrm{Sr}$ suggests that these two elements are mostly associated with biogenic carbonate. High carbonate content during interglacials suggests increased carbonate production, decreased dissolution, and/or decreased terrigenous matter dilution during warm periods, consistent with the result from a nearby core (ODP Site 1144) (Wei et al., 2004). $\mathrm{Na}_{2} \mathrm{O}_{2} \mathrm{P}_{2} \mathrm{O}_{5}$ and $\mathrm{Co}$ contents display variations that covary with those of $\mathrm{CaO}$ and $\mathrm{Sr}$ during the last interglacial and Holocene. During the last glacial, however, the contents of $\mathrm{Na}_{2} \mathrm{O}, \mathrm{P}_{2} \mathrm{O}_{5}$ and $\mathrm{Co}$ are relatively stable, whereas the contents of $\mathrm{CaO}$ and $\mathrm{Sr}$ are higher during the early MIS 3 than those in the MIS 2 and 4. While Ba and $\mathrm{Zn}$ also show distinct glacial-interglacial variations, peak enrichments of these two elements occur later than those of $\mathrm{P}_{2} \mathrm{O}_{5}$ and Co (Fig.2C).

\subsection{Elemental ratios}


Previous studies suggest that $\mathrm{Al}$ is the best proxy for terrigenous material in deep-sea sediments (Shimmield and Mowbray, 1991; Schneider et al., 1997; Wehausen and Brumsack, 2002). Although scavenged Al might exist in the SCS sediments (Wei G.J. et al., 2003), at Site 1145, good correlation $(\mathrm{r}=0.76)$ between $\mathrm{Al}_{2} \mathrm{O}_{3}$ and $\mathrm{TiO}_{2}$ demonstrates that these two elements are mainly of lithologic origin and therefore can be employed to normalize other elements. Moreover, biogenic elements (e.g., $\mathrm{Ca}, \mathrm{Ba}$, P, etc) normalized by $\mathrm{Al}$ and $\mathrm{Ti}$ show identical variations, implying that both $\mathrm{Al}$ and $\mathrm{Ti}$ can be used as the lithological elements to normalize other elements. Since Ti is complicated by heavy minerals (e.g., rutile, titanite, ilmenite), we use Al-normalized elemental ratios as in previous studies where this proxy has been applied (e.g., Wehausen and Brumsack, 2002; Clemens et al., 2008). In northern South China Sea, carbonate plays in an important role in diluting geochemical composition of the sediments (Wei et al., 2004). Down-core variations of all major and most trace elements on a carbonate-free basis exhibit similar pattern as these elemental ratios. Thus, Al normalization is a reasonable approach of correcting for dilution and assessing the enrichment of trace elements. Elemental ratios, particularly for these elements presented in one phase and diluted by a dominant phase, can be used to address regional and global paleoclimatic significances (Van der Weijden et al, 2002).

To extract the dominant modes of temporal variability from these elemental ratios, principal component analysis was carried out (Table 1). The results indicate that variability in the elemental ratios can be expressed by three principal components that together explain $71.4 \%$ of the total variance. Three elemental ratios in each principal component, which are associated with same sedimentological processes and have relatively high loadings, will be discussed further in the follow text. The first principal component (hereafter referred to as $\mathrm{PC} 1$ ), explaining $34.6 \%$ of the total variance, has relatively high loadings of $\mathrm{Ca} / \mathrm{Al}, \mathrm{P} / \mathrm{Al}$, $\mathrm{Sr} / \mathrm{Al}, \mathrm{Na} / \mathrm{Al}, \mathrm{Zn} / \mathrm{Al}, \mathrm{Co} / \mathrm{Al}, \mathrm{Ba} / \mathrm{Al}, \mathrm{Nb} / \mathrm{Al}, \mathrm{Fe} / \mathrm{Al}, \mathrm{Ni} / \mathrm{Al}, \mathrm{V} / \mathrm{Al}$ and $\mathrm{Y} / \mathrm{Al}$ (Table 1). PC1 (e.g., $\mathrm{Ca} / \mathrm{Al}, \mathrm{Ba} / \mathrm{Al}$ and $\mathrm{Sr} / \mathrm{Al}$ ) exhibits distinct glacial-interglacial variations, with higher values during the interglacial intervals than glacial periods (Fig.3A). Although these elemental ratios mainly reflect the relative contribution of biogenic matter versus terrigenous materials, peak values of the $\mathrm{Ba} / \mathrm{Al}$ are slightly lagged with respect to those of other elemental ratios during MIS 5. Such a phase difference indicates that the $\mathrm{Ba} / \mathrm{Al}$, inferred to reflect productivity 
variations (Wehausen and Brumsack, 2002), is likely forced by summer monsoon runoff at the precession band. While the $\mathrm{Fe} / \mathrm{Al}, \mathrm{Ni} / \mathrm{Al}, \mathrm{V} / \mathrm{Al}$ and $\mathrm{Y} / \mathrm{Al}$ ratios (not shown) display similar glacial-interglacial variation, their variation patterns are more complicated than those of other elemental ratios, implying that other processes (e.g., redox processes, pyritisation, and organic matter degradation) might influence these elements' concentrations (Sirocko et al., 2000).

The second component (PC2) has high loadings of $\mathrm{K} / \mathrm{Al}, \mathrm{Mg} / \mathrm{Al}, \mathrm{Rb} / \mathrm{Al}, \mathrm{Cr} / \mathrm{Al}$ and $\mathrm{Ga} / \mathrm{Al}$ (Table 1). Three elemental ratios (i.e., $\mathrm{K} / \mathrm{Al}, \mathrm{Mg} / \mathrm{Al}$ an $\mathrm{Rb} / \mathrm{Al}$ ) with relatively high loadings exhibit little glacial-interglacial variations and do not match the benthic $\delta^{18} \mathrm{O}$ record. Unlike the glacial-interglacial variations of PC1, PC2 is characterized by high-frequency and small-amplitude oscillations. Note that values of these elemental ratios are lower during the MIS 5d compared to other time intervals, indicating a weakening of weathering in the source area of the SCS sediments. This reduced weathering is probably due to the redistribution of the monsoon rainfall from the land to the ocean during the cold interval (MIS 5d) (Oppo and Sun, 2005).

The third component (PC3), with high loadings of $\mathrm{Si} / \mathrm{Al}, \mathrm{Ti} / \mathrm{Al}$ and $\mathrm{Zr} / \mathrm{Al}$ ratios, reflects the relative contribution of coarse particles versus fine-grained materials contained in the terrigenous components (Fig.3C). Values of these elemental ratios are lower during the last interglacial and Holocene relative to glacial times, implying that the input of coarse particles to the northern SCS was higher during the cold periods. Within the last interglacial interval, however, high values of these elemental ratios occurred in the MIS 5a, 5c and 5e, suggesting increased fluvial input of coarse particles during the warm interstadials.

\section{Discussion}

Geochemical composition of the SCS sediments have been investigated extensively to reconstruct the orbitally induced variability of the EAM (e.g., Wehausen and Brumsack, 2002; Wei G.J. et al., 2003, 2004). As discussed in Wehausen et al. (2003) and Wei et al. (2004), variations in major and trace elements of the SCS sediments are controlled mainly by the following factors: (1) change in the source areas of the sediments, (2) the relative contribution of the biogenic/terrigenous material, (3) chemical weathering in the source areas 
and (4) grain-size sorting during the transportation processes. However, it is difficult to differentiate the influence of these factors on the geochemical indicators. By evaluating the dominant factors controlling each principal component, addressed in the following section, we provide fresh insights into the controls on geochemical compositions of the SCS sediments.

Mineralogical, sedimentological and geochemical evidence suggests that the most important source of the terrigenous components to Site 1145 is the Pearl River, which has an annual discharge of $316 \times 10^{9} \mathrm{~m}^{3} / \mathrm{yr}$, delivering $110 \times 10^{8}$ tons of suspended load per year into the South China Sea (Zhang et al., 1994; Boulay et al., 2005). For example, ${ }^{87} \mathrm{Sr} /{ }^{86} \mathrm{Sr}$ and $\varepsilon \mathrm{Nd}(0)$ isotopic data from ODP Site 1145 sediments, combined with the smectite / (illite+chlorite) ratio, indicate that the Pearl River is the main contributor of detrital materials to the northern margin of the SCS (Boulay et al., 2005). Other possible sources are weathered materials from Taiwan (Shao et al., 2001) and eolian inputs from northern China (Duce et al., 1991; Wang et al., 1999). La-Th-Sc and Th-Sc-Zr/10 discrimination diagrams as well as the $\mathrm{Nd}$ isotopic composition of the sediments from a nearby core (ODP Site 1144) exhibit no change over the last two glacial cycles (Wei et al., 2004), suggesting that the provenance of the SCS sediments has not changed significantly during the last glacial/interglacial cycle. Therefore, variations of the elemental records cannot be attributed to changes in the sources of the northern SCS sediments.

The relative contribution of the biogenic versus terrigenous matter in the SCS sediments can be inferred from $\mathrm{PC} 1$, particularly the $\mathrm{Ca} / \mathrm{Al}$ and $\mathrm{Sr} / \mathrm{Al}$ ratios that are controlled mainly by changes in the production and/or dissolution of carbonate fraction and/or dilution by terrigenous materials. Carbonate cycles and their controlling factors are complicated in the SCS depending on the location and depth of each core (Wang, 1999). Since Site 1145 is located within the depth of present-day lysocline (3000-3200 m), it is especially sensitive to any change of sea level, seawater properties, and primary productivity (Shipboard Scientific Party, 2000). Coarse fraction flux ( $>150 \mu \mathrm{m}$, mainly calcium foraminifera) at a nearby core (Site 1146) ranges from 11 to $90 \mathrm{~g} \mathrm{~cm}^{-1} \mathrm{kyr}^{-2}$, indicating that dissolution may also play a role in driving carbonate concentration in the northern SCS within the last $150 \mathrm{ka}$ (Steven Clemens, unpublished data). In contrast, $\mathrm{Ba} / \mathrm{Al}$ ratio ranges from 62 to $98 \times 10^{-4}$ at Site 1145 
and is higher than the lithogenic background value in the SCS $\left(<70 \times 10^{-4}\right)$ except for several short cold intervals. Therefore, $\mathrm{Ba} / \mathrm{Al}$ ratio is likely a better paleoproductivity indicator than either $\mathrm{Ca} / \mathrm{Al}$ or PC1 (Shimmield and Mowbray, 1991; Wehausen and Brumsack, 2002).

Variations of $\mathrm{Ba} / \mathrm{Al}$, PC1, Hulu/Sanbao speleothem $\delta^{18} \mathrm{O}$ record (Wang et al., 2008) and the Indian summer monsoon stack (ISMS) (Clemens and Prell, 2003) are shown in Fig. 4. Cross-spectral comparison of $\mathrm{Ba} / \mathrm{Al}$ and PC1 with Earth-orbital curve (ETP: normalized eccentricity, obliquity (tilt), and precession parameters from Berger and Loutre (1991)) indicates high coherence at the precession band (Fig.5A and B). Phase results reveal that maximum $\mathrm{Ba} / \mathrm{Al}$ and $\mathrm{PC} 1$ lag maximum northern hemisphere summer insolation (precession minimum) by $144^{\circ}$ and $90^{\circ}$, respectively (Fig.6). Direct cross-spectral comparison of $\mathrm{Ba} / \mathrm{Al}$ and $\mathrm{PC} 1$ with the benthic $\delta^{18} \mathrm{O}$ record indicates that $\mathrm{Ba} / \mathrm{Al}$ and $\mathrm{PC} 1$ lag benthic $\delta^{18} \mathrm{O}$ minima by $66^{\circ}$ and $12^{\circ}$, respectively. These internally consistent phase results indicate that the timing of paleoproductivity (i.e., $\mathrm{Ba} / \mathrm{Al}$ ) in the northern SCS is nearly in phase with Indian summer monsoon proxies from the Arabian Sea (Clemens and Prell, 2003) but out of phase with Hulu/Sanbao speleothem $\delta^{18} \mathrm{O}$ record, which lags precession minima by $42^{\circ}$ (Wang et al., 2008) (Fig.6).

Previous work suggested that chemical weathering intensity in the source region might be a dominant factor controlling variations of these elemental ratios (e.g., Wei et al., 2004). In weathering profiles, $\mathrm{Al}$ is resistant to leaching during chemical weathering and is enriched in weathering products (Nesbitt and Markovics, 1997). In contrast, $\mathrm{K}, \mathrm{Mg}$ and $\mathrm{Rb}$ are easily removed from the primary minerals during chemical weathering (Nesbitt et al., 1980). Therefore, the $\mathrm{K} / \mathrm{Al}$ ratio, caused by fluctuations in weathering intensity, has been investigated to reconstruct variations in the West African monsoon (Schneider et al., 1997). Since the terrigenous components in the northern SCS are derived mainly from southern China, variation of $\mathrm{PC} 2$, with relatively high loadings of $\mathrm{K} / \mathrm{Al}, \mathrm{Mg} / \mathrm{Al}, \mathrm{Rb} / \mathrm{Al}$, probably reflects the chemical weathering intensity of the sediments from southern China. Unlike the large amplitude fluctuations of PC1, PC2 displays rapid oscillations with no significant glacial-interglacial difference, except for a notable trough during MIS 5d (Fig.4E). Weak correspondence between PC2 variation and ETP curve (Fig.5C) confirms that the source of the SCS sediments has not experienced significant changes in the intensity of chemical 
weathering during the last climatic cycle.

Sediment input changes, especially with respect to grain size sorting, are often revealed by variations in silt quartz and heavy minerals relative to aluminosilicate minerals, e.g., Ti/Al and $\mathrm{Zr} / \mathrm{Al}$ ratios (Shimmield and Mowbray, 1991). Thus, PC3 variation mainly reflects the grain size sorting effect on the elemental compositions of detrital minerals in the SCS.

Previous investigations in this area have associated grain-size variability with enhanced eolian input during glacial stages (Wang et al., 1999). A more recent study suggests that grain size variations of the sediments from two nearby core (ODP Sites 1144 and 1146) are controlled mainly by sea level change and monsoon rainfall (Boulay et al., 2007).

Comparison of PC3 with the benthic $\delta^{18} \mathrm{O}$ and speleothem $\delta^{18} \mathrm{O}$ records suggest a mixed influence of sea level change and summer monsoon intensity on grain size variations (Fig.4). On glacial-interglacial scales, PC3 variation is controlled mainly by sea level change, e.g., high contribution of coarse particle during the glacial stages when the sea level was lower. However, during MIS 5 and 3, higher elemental ratios occurred in warm periods (e.g., 3c, 5a, $5 \mathrm{c}$ and 5e), implying that intensified rainfall as evidenced by the Hulu/Sanbao $\delta^{18} \mathrm{O}$ record can also transport more coarse particles to the northern SCS. However, coherency between PC3 and ETP curve at the precession band indicates that impact of monsoon-related precipitation on PC3 is less clear relative to sea level change during the last climatic cycle (Fig.5D).

\section{Conclusions}

Major and trace element results indicate that the sediments of Site 1145 are dominated by terrigenous and biogenic components. Changes in the elemental concentrations (except for $\mathrm{V}$, Ni and Y) show significant oscillations over the last glacial-interglacial cycle. Principal component analysis reveals three dominant modes of variability. PC1 (e.g., $\mathrm{Ba} / \mathrm{Al}, \mathrm{Ca} / \mathrm{Al}$, $\mathrm{Sr} / \mathrm{Al}$ ) displays significant variance at orbital scales and is related to paleoproductivity in the northern SCS. PC2 (e.g., K/Al, Rb/Al, Mg/Al) reflects the degree of chemical weathering in the source region of the northern SCS sediment, and appears relatively stable over the last glacial-interglacial cycle. PC3 (e.g., Ti/Al, Zr/Al) reflects the relative contribution of coarseand fine-grained materials in the terrigenous components of SCS sediments, and exhibits a 
complex pattern that suggests a response to sea level change and the EAM.

Temporal variations of $\mathrm{Ba} / \mathrm{Al}$ and $\mathrm{PC} 1$ are dissimilar to those expressed in speleothem $\delta^{18} \mathrm{O}$ records and northern hemisphere summer insolation, but closely match Indian summer monsoon proxies from the Arabian Sea. Weak correlation between PC2 variations and summer insolation indicates that the degree of chemical weathering in the source area (i.e., Southern China) has not experienced significant change during the last climatic cycle. Large-amplitude oscillations of PC3 confirm that the grain size sorting of SCS sediments is controlled mainly by changes in sea level and monsoon-related runoff (Boulay et al., 2007). Cross-spectral results further indicate that paleoproductivity in the northern SCS has a clear response to precessional forcing, whereas the degree of chemical weathering in the source area is not sensitive to precessional forcing during the last climatic cycle.

\section{Acknowledgment}

This study was supported by the NSFC to Y.B. Sun and the US NSF to D.W. Oppo (OCE 0502960) and S.C. Clemens (OCE 0352215). Christian März and two anonymous reviewers gave insightful comments on this manuscript. Samples were provided by the Ocean Drilling Program (ODP), which is sponsored by the U.S. National Science Foundation (NSF) and participating countries under management of Joint Oceanographic Institutions (JOI), Inc.

\section{References}

An, Z.S., 2000. The history and variability of the East Asian paleomonsoon climate.

Quaternary Science Reviews 19, 171-187.

Berger, A., Loutre, M.F., 1991. Insolation values for the climate of the last 10 million years. Quaternary Science Reviews 10, 297-317.

Boulay, S., Colin, C., Trentesaux, A., Frank, N., Liu, Z., 2005. Sediment sources and East Asian monsoon intensity over the last $450 \mathrm{ky}$. Mineralogical and geochemical investigations on South China Sea sediments. Palaeogeography Palaeoclimatology Palaeoecology 228, 260-270. 
Boulay, S., Colin, C., Trentesaux, A., Clain S., Liu, Z.F., Lauer-Leredde, C., 2007.

Sedimentary responses to the Pleistocene climatic variations recorded in the South China Sea. Quaternary Research 68, 162-172.

Chen, M.T., Shiau, L.J., Yu, P.S., Chiu, T.C., Chen, Y.G., Wei, K.Y., 2003. 500,000-Year records of carbonate, organic carbon, and foraminiferal sea-surface temperature from the southeastern South China Sea (near Palawan Island). Palaeogeography Palaeoclimatology Palaeoecology 197, 113-131.

Clemens, S.C., Prell, W.L., 2003. A 350,000 year summer-monsoon multi-proxy stack from the Owen Ridge, Northern Arabian Sea. Marine Geology 201, 35-51.

Duce, R.A., Liss, P.S., Merrill, J.T., Atlas, L.L., Buat-Menard, P., Hicks, B.B., Miller, J.M., Prospero, J.M., Arimoto, R., Church, T.M., Ellis, W., Galloway, J.N., Hansen, L., Jickells, T.D., Knap, A.H., Reinhardt, K.H., Schneider, B., Soudine, A., Tokos, J.J., Tsunogai, S., Wollast, R., Zhou, M., 1991. The atmospheric input of trace species to the world ocean. Global Biogeochemical Cycles 5, 193-259.

Jolliffe I.T., 2002 Principal Component Analysis, Series: Springer Series in Statistics, 2nd ed., Springer, NY, p. 28.

Kienast, M., Steinke, S., Stattegger, K., Calvert, S.E., 2001. Synchronous tropical south China Sea SST change and Greenland warming during deglaciation. Science 291, 2132-2134.

Levitus, S., Boyer, T., 1994. World Ocean Atlas, v. 4: Temperature. NOAA Atlas NESDIS 4, U.S. Department of Commerce, Washington, D.C.

Liu, Z., Trentesaux, A., Clemens, S., Colin, C., Wang, P., 2003. Clay mineral assemblages in the northern South China Sea: implications for East Asian monsoon evolution over the past 2 million years. Marine Geology 201, 133-146.

Martinson, D.G., Pisias, N.G., Hays, J.D., Imbrie, J., Moore, T.C., and Shackleton, N.J., 1987. Age dating and the orbital theory of the ice ages: Development of a high-resolution 0 to 300,000 year chronostratigraphy. Quaternary Research 27, 1-29.

Nesbitt, H.W., Markovics, G., Price, R.C., 1980. Chemical processes affecting alkalis and alkaline earths during continental weathering. Geochimica et Cosmochimica Acta 44, 1659- 1666. 
Nesbitt, H.W., Markovics, G., 1997. Weathering of grandioritic crust, long-term storage of elements in weathering profiles, and petrogenesis of siliciclastic sediments. Geochimica et Cosmochimica Acta 61, 1653-1670.

Oppo, D.W., Sun, Y.B., 2005. Amplitude and timing of sea-surface temperature change in the northern South China Sea: Dynamic link to the East Asian monsoon. Geology 33, 785-788.

Pelejero, C., Heilig, J.O., Kienast, M., Wang, L.J., 1999. High-resolution $\mathrm{U}_{\mathrm{k}}{ }^{37}$ temperature reconstructions in the South China Sea over the past 220 kyr. Paleoceanography 14, 224-231.

Schneider, R.P., Price, N.B., Muller, P.J., Kroon, D., Alexander, I., 1997. Monsoon related variations in Zaire (Congo) sediment load and in£uence of fluvial silicate supply on marine productivity in the east equatorial Atlantic during the last 200,000 years. Paleoceanography 12, 463-481.

Shao, L., Li, X.H., Wei, G.J., Liu, Y., Fang, D.Y., 2001. Provenance of a prominent sediment drift on the northern slope of the South China Sea. Science in China (Series D) 44, 919-925.

Shimmield, G.B., Mowbray, S.R., 1991. The inorganic geochemical record of the northwest Arabian Sea: a history of productivity variation over the last $400 \mathrm{kyr}$ from Sites 772 and 724, in: W.L. Prell et al. (Eds.), Proceeding of Ocean Drilling Program, Scientific Results $117,409-429$.

Shipboard Scientific Party, Site 1145, 2000, In Wang, P., Prell, W.L., Blum, P., et al., Proc. ODP, Init. Repts., 184, 1-63 [CD-ROM]. Available from: Ocean Drilling Program, Texas A\&M University, College Station TX 77845-9547, USA, 2000.

Sirocko, F., Garbe-Schonberg, D., Colin, D., 2000, Processes controlling trace element geochemistry of Arabian Sea sediments during the last 25,000 years. Global and Planetary Change 26, 213-303.

Sun, X.J, Luo, Y.L., Huang, F., Tian, J., Wang, P.X, 2003. Deep-sea pollen from the South China Sea: Pleistocene indicators of East Asian monsoon. Marine Geology 201, 97-118. Tamburini, F., Adatte, T., Follmi, K., Bernasconi, S.M., Steinmann, P., 2003. Investigating the history of East Asian monsoon and climate during the last glacial-interglacial period 
(0-140 000 years): mineralogy and geochemistry of ODPSites 1143 and 1144, South China Sea. Marine Geology 201, 147-168.

Van der Weijden, G.H., 2002. Pitfalls of normalization of marine geochemical data using a common divisor. Marine Geology 184, 167-187.

Wang, L., Wang, P., 1990. Late Quaternary paleoceanography of the South China Sea: glacial-interglacial contrasts in an enclosed basin. Paleoceanography 5, 77-90.

Wang, L.J., Sarnthein, M., Erlenkeuser, H., Grimalt, J., Grootes, P. M., Heilig, J. O., Ivanova, E., Kienast, M., Pelejero, C., Pflaumann, U., 1999. East Asian monsoon climate during the Late Pleistocene: high resolution sediment records from the South China Sea. Marine Geology 156, 245-284.

Wang, P., Wang, L., Bian, Y., Jian, Z., 1995. Late Quaternary paleoceanography of the South China Seas: surface circulation and carbonate cycles. Marine Geology 127, 145-165.

Wang, P.X., 1999. Response of Western Pacific marginal seas to glacial cycles: paleoceanographic and sedimentological features. Marine Geology 156, 5-39.

Wang, P.X., Clemens, S, Beaufort, L., Braconnot, P., Ganssene, G., Jian, Z.M., Kershaw, P., Michael Sarnthein, M., 2005, Evolution and variability of the Asian monsoon system: state of the art and outstanding issues. Quaternary Science Reviews 24, 595-629.

Wang, Y.J., Cheng, H., Adwards, R.L., Kong, X.G., Shao, X.H., Chen, S.T., Wu, J.Y., Jiang, X.Y., Wang, X.F., An, Z.S., 2008, Millennial- and orbital-scale changes in the East Asian monsoon over the past 224,000 years. Nature 451, 1090-1093.

Wehausen, R., Brumsack, H.-J., 2002. Astronomical forcing of the East Asian monsoon mirrored by the composition of Pliocene South China Sea sediments. Earth and Planetary Science Letters 201, 621-636.

Wehausen, R., Tian, J., Brumsack, H.-J., Cheng, X.R., Wang, P.X., 2003. Geochemistry of Pliocene sediments from ODP site 1143 (southern South China Sea). in: W.L. Prell et al. (Eds.), Proceeding of Ocean Drilling Program, Scientific Results 184, 1-25.

Wei, G.J., Liu, Y., Li, X.H., Chen, M.H., Wei, W.C., 2003. High resolution elemental records from the South China Sea and their paleoproductivity implications. Paleoceanography 18, 1054-1065.

Wei, G.J., Liu, Y., Li, X.H., Shao, L., Fang, D.Y., 2004. Major and trace element variations 
of the sediments at ODP Site 1144, South China Sea, during the last $230 \mathrm{ka}$ and their paleoclimate implications. Palaeogeography Palaeoclimatology Palaeoecology 212, 331-342.

Wei, K. Y., Chiu, T.C., Chen, Y.G., 2003. Toward establishing a maritime proxy record of the East Asian monsoon. Marine Geology 201, 67-79.

Zhao, M.X., Huang, C.Y., Wang, C.C., 2006. A millennial-scale U-37(K ') sea-surface temperature record from the South China Sea (8 degrees N) over the last 150 kyr: Monsoon and sea-level influence. Palaeogeography Palaeoclimatology Palaeoecology 236, 39-55.

Zhang, C.S., Wang, L.J., Li, G.S., Dong, S.S., Yang, J.R., Wang, X.L., 2002. Grain size effect on multi-element concentrations in sediments from the intertidal flats of Bohai Bay, China. Applied Geochemistry 17, 59-68.

Zhang J., Huang W., Liu M., 1994. Geochemistry of major Chinese river-estuary systems, in: Zhou Di et al. (Eds.), Oceanology of China Seas, Vol. 1, Kluwer Academic, Dordrecht. 179-188. 
Table 1. Results of principal component analyses for the Al-normalized elemental ratios of ODP site 1145 sediments in the North SCS. Three principal components (PC) can be derived from twenty elemental ratios, which explain 34.6\% (PC1), 18.6\% (PC2) and 18.2\% (PC3) of the total variance, respectively. Mean and standard deviation (STD) of the elemental ratios are also shown. Three elemental ratios with relatively high loadings in each principal component are underlined.

\begin{tabular}{c|c|c|c}
\hline & PC1 & PC2 & PC3 \\
\hline $\mathrm{Si} / \mathrm{Al}$ & 0.20 & -0.15 & $\underline{0.88}$ \\
\hline $\mathrm{Fe} / \mathrm{Al}$ & 0.53 & 0.32 & 0.23 \\
\hline $\mathrm{Mg} / \mathrm{Al}$ & 0.25 & $\underline{0.72}$ & -0.32 \\
\hline $\mathrm{Ca} / \mathrm{Al}$ & $\underline{0.84}$ & 0.13 & 0.32 \\
\hline $\mathrm{Na} / \mathrm{Al}$ & 0.76 & 0.17 & 0.26 \\
\hline $\mathrm{K} / \mathrm{Al}$ & 0.03 & $\underline{0.81}$ & 0.25 \\
\hline $\mathrm{Ti} / \mathrm{Al}$ & 0.41 & 0.00 & $\underline{0.86}$ \\
\hline $\mathrm{Ba} / \mathrm{Al}$ & 0.79 & -0.20 & 0.22 \\
\hline $\mathrm{P} / \mathrm{Al}$ & 0.76 & 0.07 & 0.51 \\
\hline $\mathrm{Ga} / \mathrm{Al}$ & 0.29 & 0.70 & -0.02 \\
\hline $\mathrm{Rb} / \mathrm{Al}$ & -0.34 & $\underline{0.86}$ & -0.07 \\
\hline $\mathrm{Sr} / \mathrm{Al}$ & $\underline{0.86}$ & 0.14 & 0.31 \\
\hline $\mathrm{Y} / \mathrm{Al}$ & 0.53 & 0.43 & 0.47 \\
\hline $\mathrm{Zr} / \mathrm{Al}$ & 0.17 & 0.25 & $\underline{0.86}$ \\
\hline $\mathrm{Nb} / \mathrm{Al}$ & -0.85 & 0.08 & 0.26 \\
\hline $\mathrm{V} / \mathrm{Al}$ & 0.69 & 0.18 & 0.28 \\
\hline $\mathrm{Cr} / \mathrm{Al}$ & 0.24 & 0.68 & 0.22 \\
\hline $\mathrm{Co} / \mathrm{Al}$ & 0.76 & 0.48 & -0.07 \\
\hline $\mathrm{Ni} / \mathrm{Al}$ & 0.44 & 0.28 & -0.32 \\
\hline $\mathrm{Zn} / \mathrm{Al}$ & 0.78 & 0.19 & 0.22 \\
\hline & & & \\
\hline
\end{tabular}




\section{Figure captions}

Fig.1. Map showing locations of ODP Sites 1145, 1144, 1146, Hulu cave ,and Sanbao cave. Dashed lines represent the $100 \mathrm{~m}$ (approximate position of coastline during glacial low sea level) and $3000 \mathrm{~m}$ (approximate depth of present-day lysocline) isobaths in the South China Sea.

Fig.2. Temporal variations of major and trace element concentrations of sediments at ODP Site 1145: (A) elements enriched in clay- and silt-sized minerals, (B) Ca and Sr mostly associated with biogenic carbonate while $\mathrm{Na}$ partly influenced by salt precipitated from pore waters, (C) elements related to oceanic productivity and organic matter burial, and (D) elements whose enrichment mechanisms are still less clear. Benthic $\delta^{18} \mathrm{O}$ record from Oppo and Sun (2005) is shown as a reference curve, with marine isotope stages (MIS) to the left.

Fig.3. Variations of the Al-normalized elemental ratios: (A) PC1-elemental ratios mainly related to paleoproductivity, (B) PC2-elemental ratios associated with the degree of chemical weathering in the source regions, (C) PC3-elemental ratios controlled by grain size sorting. The benthic $\delta^{18} \mathrm{O}$ record (Oppo and Sun, 2005) is also shown as a reference curve.

Fig.4. Comparison of multiple proxy indicators generated from Site 1145 with Indian summer monsoon stack (ISMS) and speleothem $\delta^{18} \mathrm{O}$ record from Hulu/Sanbao caves. (A) Hulu/Sanbao speleothem $\delta^{18} \mathrm{O}$ record (Wang et al., 2008), (B) Ba/Al ratio, (C) PC1, (D) Indian summer monsoon stack (Clemens and Prell, 2003), (E) PC2, (F) PC3, and (G) benthic $\delta^{18} \mathrm{O}$ record (Oppo and Sun, 2005). The Hulu $\delta^{18} \mathrm{O}$ record (blue) is plotted $1.6 \%$ more negative to account for the higher Hulu values than Sanbao cave (pink). Shaded bars denote the interglacial stages and substages.

Fig.5. Cross-spectral analyses of (A) Ba/Al, (B) PC1, (C) PC2 and (4) PC3 with Earth-orbital curve (ETP) from Berger and Loutre (1991). In each diagram, the solid and dashed lines correspond to the spectrum of proxy indicators and solar insolation, respectively, both plotted on arbitrary log scales. The dotted line is coherency spectrum plotted on a hyperbolic arctangent scale and provided with a 5\% significance level.

Fig.6. Phase wheel indicating the timing of different climate proxies relative to orbital forcing 
and global ice volume at the precession band. Zero phase is defined at June 21 perihelion (Pmin, minimum precession), corresponding to maximum Northern Hemisphere summer insolation. Negative sign (clockwise) represents temporal lags. For example, minimum ice volume (benthic $\delta^{18} \mathrm{O}$ ) has a phase of $-78^{\circ}$ relative to Pmin indicating a $5 \mathrm{kyr}$ lag $\left(-78^{\circ} / 360^{\circ} \mathrm{x}\right.$ $23 \mathrm{kyr})$. 


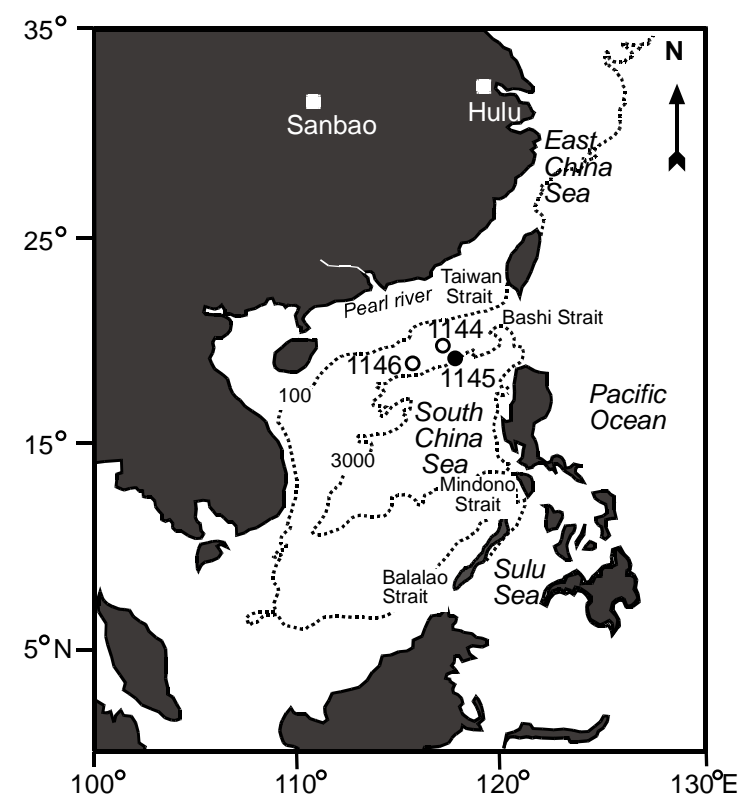

Fig.1
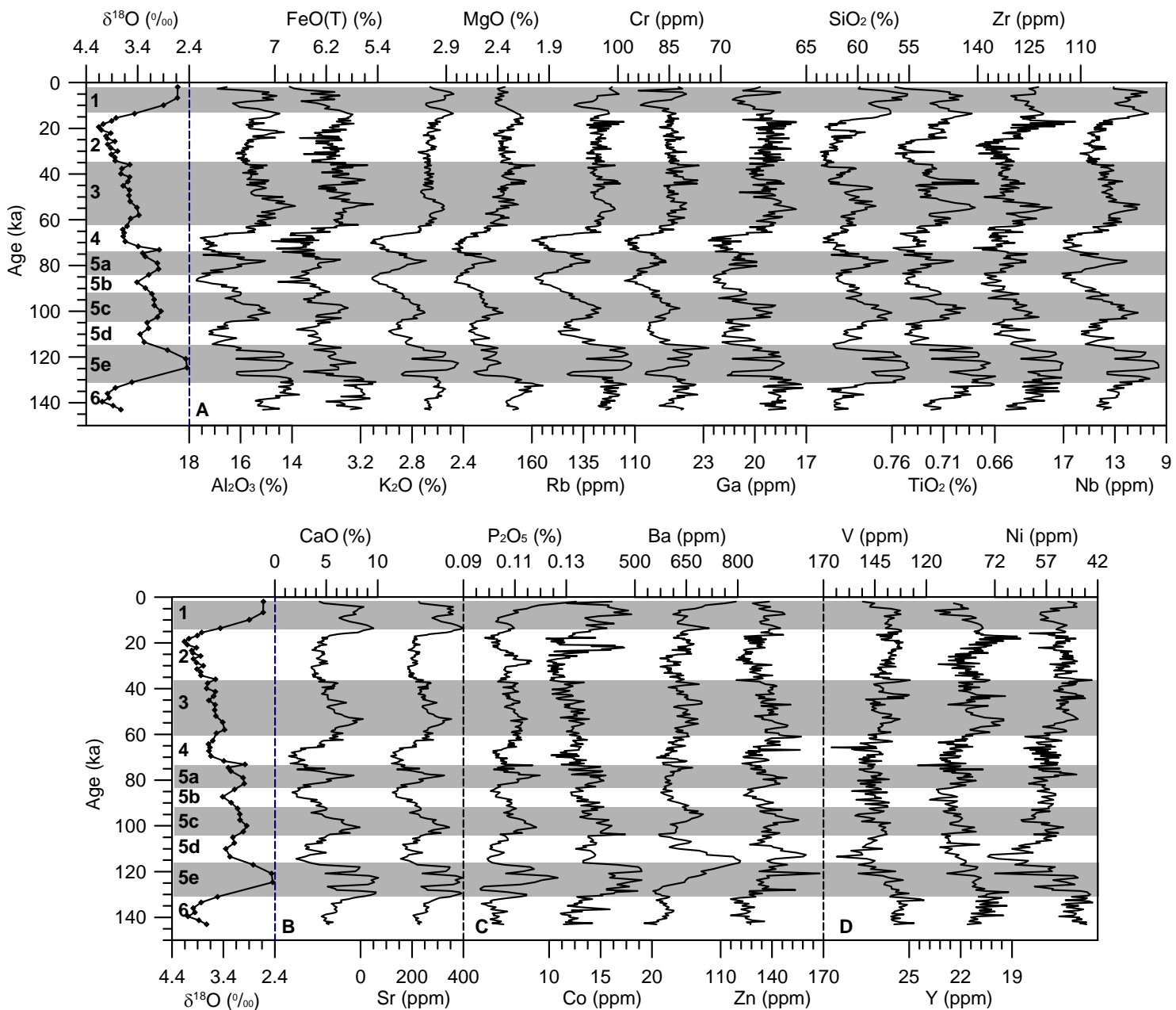

Fig.2 


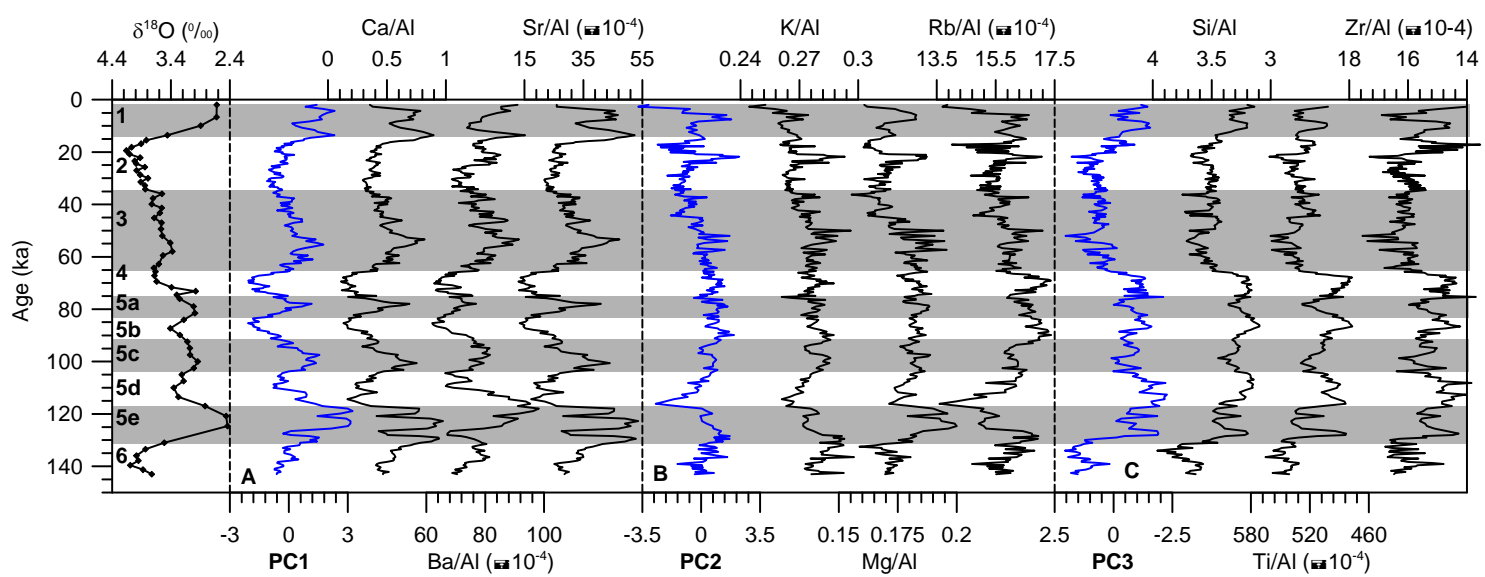

Fig.3

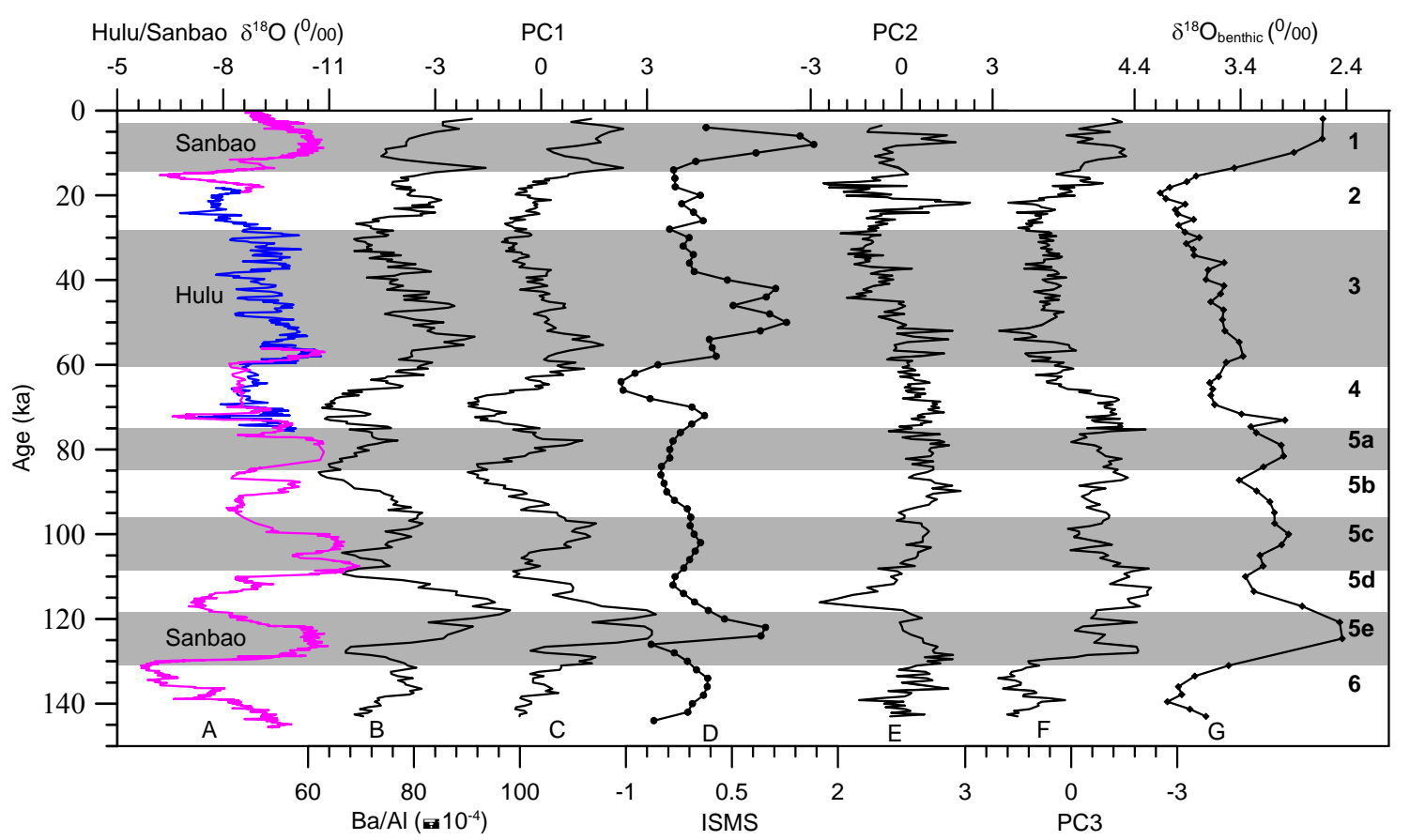

Fig.4

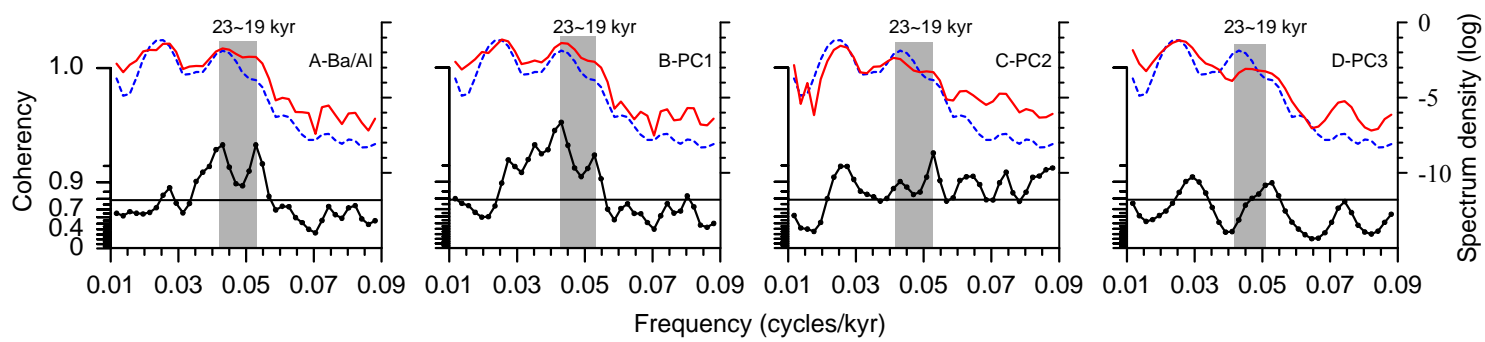

Fig.5 


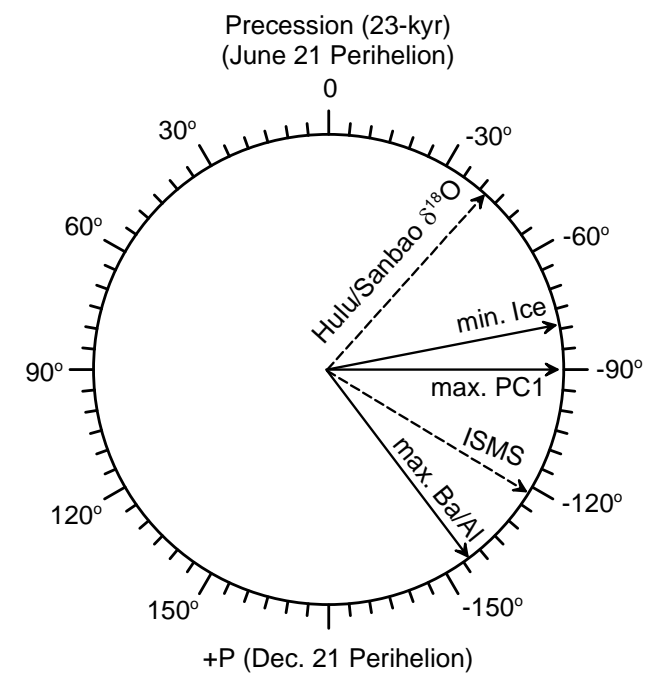

Fig.6 